Dr. Alex G. Ogg, Jr. is a Plant Physiologist (Weed Scientist) for the Agricultural Research Service, U.S. Department of Agriculture at Pullman,

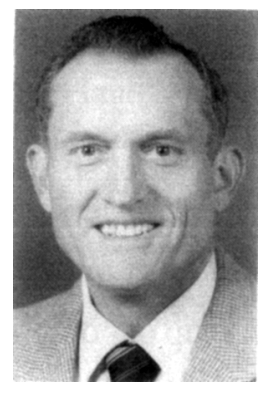
WA. For the past 10 years he has served as Research Leader for the Nonirrigated Agriculture Weed Science Research Unit. The mission of the Unit is to define weed science principles, to develop weed control strategies, and to reduce losses due to weeds in conservation cropping systems in the Pacific Northwest. Before moving to Pullman in 1984, Alex spent 15 years at Prosser,

WA working for ARS on weed management systems in horticultural and specialty crops. Dr. Ogg's career as a weed scientist spans 31 years. His research programs have always focused on solving weed problems and helping farmers manage weeds more efficiently. His major research efforts have been in developing the practice of applying herbicides through irrigation systems, in clarifying the taxonomy and developing control practices for nightshade (Solanum spp.), in discovering new information on the biology and ecology of downy brome (Bromus tectorum L.) and jointed goatgrass (Aegilops cylindrica Host) and in developing integrated weed management systems for asparagus (Asparagus officinalis L.), American hop (Humulus americanus Nutt.), mint (Mentha spp.), potato (Solanum tuberosum $L$.), tree fruits, vegetable crops, grain legumes, and winter wheat (Triticum aestivum L.).

Ogg received his B.S. degree from the University of Wyoming. He received his M.S. degree in Farm Crops (Weed Science) and his Ph.D. degree in Botany (Plant Physiology) from Oregon State University. Dr. Ogg is a Fellow of the Western Society of Weed Science and the Weed Science Society of America. He served as President of WSSA for the 1994-1995 term.

\title{
Expanding the Weed Science Society of America Beyond Weed Science ${ }^{1}$
}

\author{
ALEX G. OGG, JR. ${ }^{2}$
}

The Weed Society of America (WSA) was organized in 1954 (4). At that time, 114 scientists were identified as conducting research on weeds and their control, although only part of these scientists' time was devoted to weeds (5). Although "selective" herbicides were used in the late 1800 s and the "sinox" or "dinitro" herbicides were fairly important from the 1930s, the discovery of the broadleaf selective phenoxy herbicides in the 1940s gave scientists and farmers an exciting new way to manage weeds and played a major role in advancing the notion that there was a need for a separate discipline of weed science. It was noted by C. J. Willard in 1954 (5) at an address to the American Society of Agronomy (ASA) that there was an urgent need for research on weed biology and ecology and on the behavior of herbicides in plants and soils. WSA held

\footnotetext{
${ }^{1}$ Presidential address given at the 35 th Annual Meeting of the Weed Sci. Soc. Am., Seattle, WA. Jan. 31, 1995. 99164.

Plant Physiol./Res. Leader, Agric. Res. Serv., U.S. Dep. Agric., Pullman, WA

${ }^{3}$ R. A. Schmidt. 1995. Personal communication; WSSA, Champaign, IL.
}

its first meeting in January, 1956. There were 621 charter members of WSA (2).

In a span of a few years, industry, university, and federal scientists had developed herbicides to the point where the farmer could control weeds selectively in corn (Zea mays L.), cotton (Gossypium hirsutum L.), soybean [Glycine $\max$ (L.) Merr.], and wheat (Triticum aestivum L.). These were exciting times for weed scientists and the WSA flourished. In 1966, the name of the Society was changed to the Weed Science Society of America (WSSA). WSSA now recognizes, even more so, the need to expand our knowledge about weed biology and ecology, economic thresholds for weeds, alternative weed control methods, and new information delivery systems (1). WSSA members also recognize that weed science will need increased state and federal funding to support these expanded research and educational efforts.

Today, about $75 \%$ of the 2200 individual members of WSSA work for private industry ${ }^{3}$. Of the approximately 450 members of WSSA that work in public institutions, 
only 250 devote more than $50 \%$ of their time to weed science research. In comparison to WSSA, the American Phytopathological Society (APS), which was organized 46 years earlier than WSSA, now has about 5000 individual members with about $85 \%$ working in public institutions ${ }^{4}$. The Entomological Society of America (ESA), which was organized about 100 years before WSSA, has over 8100 individual members with about $75 \%$ working in public institutions ${ }^{5}$. These numbers of scientists help explain why weed science receives such a small percentage of federal dollars relative to plant pathology and entomology (Table 1) (3). Note that the disciplines of plant pathology and entomology receive 8 to 10 times more federal research dollars, respectively, than does weed science.

The point of this discussion is there are too few public weed scientists relative to plant pathologists and entomologists to expect that we, working by ourselves, are going to gain significantly more federal research funds for weed science. If we expect to expand or perhaps even maintain our current funding levels for weed science, we must join with other organizations and groups who have research interests common to ours. In addition to the funding question, I believe WSSA must be more proactive in debates on issues related to agriculture. With the relatively limited resources WSSA has at its disposal, we will have a very difficult time changing public policy and funding decisions without cooperating with other organizations.

One such group that WSSA can and does cooperate with is ASA and its affiliated societies, the Crop Science Society of America (CSSA) and the Soil Science Society of America (SSSA). These three societies encompass over 12,400 individual members and they share many of WSSA's research and educational goals. I am pleased that Dr. Robert Shearman, President of CSSA, Dr. Calvin Qualset immediate Past President of ASA, and Dr. Robert F. Barnes, Executive Vice President of ASA, are in attendance at this meeting and are interested in expanding cooperative interactions between their societies and WSSA. Because we have common interests and goals, many of our members are also members of these respective societies.

Currently, WSSA is cooperating with ASA by co-sponsoring two Congressional Science Fellowships, by participating in the certification of professional weed scientists under the ARCPACS program, and by co-sponsoring sym-

\footnotetext{
${ }^{4} \mathrm{M}$. Nelson. 1995. Personal communication; APS, Madison, WI.

${ }^{5} \mathrm{~K}$. Meckley. 1995. Personal communication; ESA, Washington, DC.
}

Table 1. Federal funding for pest research at university laboratories in fiscal year 1991 (3).

\begin{tabular}{ll}
\hline $\begin{array}{l}\text { Pest management } \\
\text { discipline }\end{array}$ & $\begin{array}{l}\text { Federal } \\
\text { funding }\end{array}$ \\
\hline & Millions \$ \\
Entomology & 61 \\
Plant Pathology & 50 \\
Nematology & 9 \\
Weed Science & 6.4 \\
\hline
\end{tabular}

posia at our respective annual meetings. Without the administrative and financial support of ASA, WSSA's involvement in these programs would be reduced greatly. During this past year, as President of WSSA, I have met on several occasions with the leadership of ASA and we have identified three other ways where we might cooperate. During the past couple of years, ASA has retained the services of a congressional liaison representative to track the progress of legislative matters important to ASA and to advise them when and to whom they need to be providing information. This liaison group also represents ASA at meetings in Washington, DC and reports back to the Society on actions they need to take. Hiring a full-time liaison representative is beyond the financial capabilities of WSSA; however, by cooperating with ASA, we may have the opportunity to have the services of this liaison representative on a $25 \%$ or $50 \%$ basis.

Both ASA and WSSA have a need to provide continuing education programs for consultants and certified crop advisors. This would be an ideal way for our societies to cooperate. The number of private consultants is increasing and our traditional, brief research reports do not meet their needs. Consultants need programs within our annual meetings or perhaps special workshops that are designed to meet their specific education needs. If we participate in these programs, WSSA gains by expanding its education goal and by increasing membership and attendance at our annual meetings.

WSSA and ASA could also co-sponsor national or regional workshops on topics that are timely and need a narrow focus. Returning Conservation Reserve Program lands back to crop production is one example. I am sure there are many other areas of cooperation each of us could identify. To expand our cooperation with ASA, all we need to do is to be open to new ideas and be willing to interact.

There are several other groups or organizations in which we should consider being active. The Plant-Soil Sciences Forum Discussion Group is an informal group under the 
leadership of ASA, CSSA, SSSA, the American Society for Horticultural Science, and the American Society of Plant Physiologists, but includes many other societies such as APS and ESA. The purpose of the Forum is "to identify science, education, and technology issues associated with plant and soil sciences that are relevant to current and developing public policy deliberations." Issues discussed recently include Integrated Pest Management (IPM) in sustainable agriculture initiatives and the 1995 Farm Bill. WSSA needs to participate actively in this Forum.

This fall the Crop Science Society of America invited WSSA to endorse the concept of a Coalition for Science Education about Environment, Food, Agriculture, and Renewable Resources (CEEFAR). The purpose of CEEFAR is to develop a unified education message about environment, food, agriculture, and renewable resources for kindergarten through high school students. I am pleased to report that the WSSA Board of Directors unanimously approved our endorsement of CEEFAR. We look forward to being involved in this coalition.

The final organization that I want to mention is the Coalition on Funding Agricultural Research Missions (CoFARM). CoFARM was formed in 1990 and is an association of scientific and professional organizations that represents over 100,000 members. Its goal is to help focus the research budget of the United States Department of Agriculture (USDA) on projects essential to our country's economic well-being and public health. CoFARM advocates increased funding for agricultural research, including the National Research Initiative.

In summary, I believe WSSA must expand its horizons beyond weed science and the only way we can accomplish our goals is to become more active in developing cooperative interactions with other organizations such as those mentioned and others that will be identified.

In closing, I want to thank you for giving me the opportunity to serve as your President. It has been challenging, but it has enlightened me to the long-term needs of WSSA. Thank you.

\section{LITERATURE CITED}

1. Coble, H. D. 1994. Future directions and needs for weed science research. Weed Technol. 8:410-412.

2. Jacob, W. C. 1956. Minutes of Business Meeting, Weed Society of America Weeds 4:400-404.

3. Rockey, S. and P. Jones. 1993. Plant systems. p. 17-23 in Dynamics of the Research Investment: Issues and Trends in the Agricultural Research System. U.S. Dep. Agric., Coop. State Research Service. Washington, DC.

4. Timmons, F. L. 1970. A history of weed control in the United States and Canada. Weed Sci. 18:294-307.

5. Willard, C. J. 1954. Weed control: Past, present, prospects. Agron. J. $46: 481-484$ 